\section{The Microbial Modification of A58365A, an Angiotensin Converting Enzyme Inhibitor}

\author{
Jon S. Mynderse, David S. Fukuda \\ and ANN H. HunT
}

The Lilly Research Laboratories, Eli Lilly and Company, Indianapolis, Indiana 46285, U.S.A.

(Received for publication November 7, 1994)

We have previously reported the discovery ${ }^{1,2)}$, isolation $^{3)}$, and structure elucidation ${ }^{4)}$, of A58365A (1) and A58365B (2), a pair of angiotensin converting enzyme (ACE) inhibitors produced by fermentation of Streptomyces chromofuscus NRRL 15098. We now report the structure of a microbial modification product (3) produced from the dimethyl ester of A58365A (4). A screen of forty micro-organisms for their ability to bioconvert dimethyl A58365A (4) yielded an organism, Streptomyces rimosus, NRRL 2234, capable of converting 4 to a more polar derivative in high yield. A scale-up was performed to provide sufficient $\mathbf{3}$ for structural elucidation. Seventy-five milligrams of $\mathbf{4}$ was incubated with $150 \mathrm{ml}$ of Streptomyces rimosus at $30^{\circ} \mathrm{C}$ in shaken flasks for 48 hours. The culture was filtered to remove the mycelium and the filtrate loaded onto a column of Diaion HP-20 adsorbent. The conversion product 3 was eluted with acetonitrile - water $(1: 1)$. Final purification was afforded by reversed phase HPLC on Dupont Zorbax-ODS using a mobile phase of acetonitrile - water formic acid $(8.0: 91.8: 0.2)$ to give $47 \mathrm{mg}$ of pure $3 ;[\alpha]_{589}^{25}$ $+154.5^{\circ}$ ( $c 6.5$, water). The structure of 3 was derived by examining results from ${ }^{1} \mathrm{H}$ NMR, ${ }^{13} \mathrm{C}$ NMR, and UV spectroscopies and from field desorption mass spectrometry, and by comparing these results to similar data for compounds 1 and 4 .

The UV spectra of $\mathbf{1}, \mathbf{3}$, and $\mathbf{4}$ in methanol solution are summarized in Table 1 . The conversion product retains the pyridone chromophore of A58365A (1) but the chromophore no longer contains a titratable group, suggesting that the modification of $\mathbf{4}$ to produce $\mathbf{3}$ has involved a change at $\mathbf{R}_{3}$. The field desorption mass spectrum of 3 exhibits major peaks at $m / z 454\left(\mathrm{M}+\mathrm{H}^{+}\right)$, $453\left(\mathrm{M}^{+}\right)$, and $295\left([\mathrm{M}-158]^{+}\right)$. The molecular weight of dimethyl A58365A (4) is 295, suggesting that modification of 4 to form 3 involved the addition of a single moiety which is readily cleaved in the mass spectrometer.

The ${ }^{1} \mathrm{H}$ NMR spectrum of 3 was examined in $\mathrm{D}_{2} \mathrm{O}$ solution, using the solvent resonance as a chemical shift reference (residual HDO $4.80 \mathrm{ppm}$ ); the spectrum is very similar to that of $\mathbf{4}$, with two exceptions: the aromatic singlet at $7.33 \mathrm{ppm}$ in $\mathbf{4}$ (proton at position 7) is shifted to $7.61 \mathrm{ppm}$ in 3 , and there are four new single-proton resonances. The proton spectra of $\mathbf{3}$ and $\mathbf{4}$ are compared in Table 2. Decoupling experiments indicated the following connectivity for the four new resonances of $\mathbf{3}$ : $-\mathrm{CH}(6.07 \mathrm{ppm})-\mathrm{CH}(4.23 \mathrm{ppm})-\mathrm{CH}(4.13 \mathrm{ppm})-\mathrm{CH}$ $(5.54 \mathrm{ppm})-$. The $5.54 \mathrm{ppm}$ resonance and the peak at $7.61 \mathrm{ppm}$ each exhibit small NOEs when the other is irradiated, indicating that they are in close spatial proximity. The $6.07 \mathrm{ppm}$ doublet sharpens slightly when the $4.13 \mathrm{ppm}$ triplet is irradiated, removing a small four-bond coupling.

Table 1. Ultraviolet spectroscopy of $\mathbf{1}, \mathbf{3}$, and $\mathbf{4}^{*}$.

\begin{tabular}{|c|c|c|}
\hline Compound & Neutral solution & After addition of base \\
\hline 1 & $\lambda=325 \mathrm{~nm}(\varepsilon=7,600)$ & $\lambda=353 \mathrm{~nm}(\varepsilon=7,400)$ \\
\hline & $\lambda=232 \mathrm{~nm}(\varepsilon=6,000)$ & $\lambda=243 \mathrm{~nm}(\varepsilon=7,200)$ \\
\hline 3 & $\begin{array}{l}\lambda=317 \mathrm{~nm}(\varepsilon=6,850) \\
\lambda=233 \mathrm{~nm}(\varepsilon=10,700)\end{array}$ & No change \\
\hline 4 & $\begin{array}{l}\lambda=333 \mathrm{~nm} \\
\lambda=235 \mathrm{~nm}\end{array}$ & $\begin{array}{l}\lambda=362 \mathrm{~nm} \\
\lambda=246 \mathrm{~nm}\end{array}$ \\
\hline
\end{tabular}

* UV spectra recorded on a Cary 118 spectrometer; solvent $=$ methanol.

Fig. 1. Structures of A58365 ACE inhibitors and modification products.<smiles>O=C(O)CCc1cc(O)c2n(c1=O)C(C(=O)O)CC2</smiles>

$1 \quad R_{1}=R_{2}=R_{3}=H$

$4 \quad R_{1}=R_{2}=C_{3}, \quad R_{3}=H$

$3 \quad \mathrm{R}_{1}=\mathrm{R}_{2}=\mathrm{CH}_{3}, \quad \mathrm{R}_{3}=\mathrm{X}$

$5 \quad R_{1}=R_{2}=H, \quad R_{3}=X$<smiles>O=C(O)CCc1cc(O)c2n(c1=O)C(C(=O)O)CCC2</smiles> 
Table 2. Proton NMR comparison of 3 and 4; chemical shifts $(\delta)$ and coupling constants $(J)^{*}$.

\begin{tabular}{cll}
\hline Position & $\begin{array}{c}4 \delta(\mathrm{ppm}), \\
\text { multiplicity }\end{array}$ & $\begin{array}{c}\text { 3 } \delta(\mathrm{ppm}), \\
\text { multiplicity, } J(\mathrm{~Hz})\end{array}$ \\
\hline 2 & $5.13(1 \mathrm{H}, \mathrm{dd})$ & $5.22(1 \mathrm{H}, \mathrm{dd} ; J=10,4)$ \\
3 & $2.50(1 \mathrm{H}, \mathrm{m})$, & $2.62(1 \mathrm{H}, \mathrm{m})$, \\
& $2.30(1 \mathrm{H}, \mathrm{m})$ & $2.36(1 \mathrm{H}, \mathrm{m})$ \\
4 & $3.11(2 \mathrm{H}, \mathrm{t})$ & $3.19(2 \mathrm{H}, \mathrm{t} ; J=8)$ \\
7 & $7.33(1 \mathrm{H}, \mathrm{s})$ & $7.61(1 \mathrm{H}, \mathrm{s})$ \\
9 & $2.80(2 \mathrm{H}, \mathrm{m})$ & $2.81(2 \mathrm{H}, \mathrm{t} ; J=7)$ \\
10 & $2.63(2 \mathrm{H}, \mathrm{t})$ & $2.68(2 \mathrm{H}, \mathrm{t} ; J=7)$ \\
$\left(\begin{array}{c}\mathrm{R}_{1}, \\
\mathrm{R}_{2}\end{array}\right.$ & $3.75(3 \mathrm{H}, \mathrm{s})$, & $3.81(3 \mathrm{H}, \mathrm{s})$, \\
& $3.63(3 \mathrm{H}, \mathrm{s})$ & $3.67(3 \mathrm{H}, \mathrm{s})$ \\
& & $6.07(1 \mathrm{H}, \mathrm{d} ; J=4)$ \\
& & $5.54(1 \mathrm{H}, \mathrm{d} ; J=3.5)$ \\
& & $4.23(1 \mathrm{H}, \mathrm{t} ; J \sim 3.5)$ \\
& & $4.13(1 \mathrm{H}, \mathrm{t} ; J \sim 3.5)$
\end{tabular}

* ${ }^{1} \mathrm{H}$ NMR spectrum of 4 recorded in $\mathrm{CDCl}_{3}$; spectrum of 3 recorded in $\mathrm{D}_{2} \mathrm{O}$. Spectra recorded using a Bruker WH360 spectrometer.

Table 3. Carbon NMR parameters for 4 and $3 *$

$\left.\begin{array}{ccc}\hline \multicolumn{1}{c}{\begin{array}{c}3 \delta(\mathrm{ppm}), \\ \text { multiplicity, coupling }\end{array}} & \text { Assignment } \\ \hline 173.45 & 176.68 \mathrm{~s} & 11 \\ 170.55 & 173.20 \mathrm{~s} & 1 \\ & 166.13 \mathrm{~s} & 6^{\prime} \\ 158.86 & 161.26 \mathrm{~s} & 12 \\ & 141.90 \mathrm{~s} & 5^{\prime} \\ 135.25 & 141.53 \mathrm{~s} & 6 \\ 133.83 & 136.50 \mathrm{~d} ;{ }^{1} \mathrm{H}=7.61 & 7 \\ 132.16 & 136.13 \mathrm{~s} & 5 \\ 128.54 & 129.29 \mathrm{~s} & 8 \\ & 112.90 \mathrm{~d} ;{ }^{1} \mathrm{H}=6.07 ;{ }^{1} J_{\mathrm{C}-\mathrm{H}}=171 \mathrm{~Hz} & 4^{\prime} \\ & 101.57 \mathrm{~d} ;{ }^{1} \mathrm{H}=5.54 ;{ }^{1} J_{\mathrm{C}-\mathrm{H}}=173 \mathrm{~Hz} & 1^{\prime} \\ & 70.09 \mathrm{~d} ;{ }^{1} \mathrm{H}=4.13 & 2^{\prime} \\ & 66.17 \mathrm{~d} ;{ }^{1} \mathrm{H}=4.23 & 3^{\prime} \\ 2 & \mathbf{R}_{1} \\ 62.10 & 63.93 \mathrm{~d} & \mathbf{R}_{2}\end{array}\right)$

* ${ }^{13} \mathrm{C} \mathrm{NMR}$ spectrum of 4 recorded in $\mathrm{CDCl}_{3}$; spectra of 3 recorded in $\mathrm{D}_{2} \mathrm{O}$. Spectra recorded using a Bruker WM270 spectrometer.

The ${ }^{13} \mathrm{C}$ NMR spectrum of 3 was examined in $\mathrm{D}_{2} \mathrm{O}$ solution using internal dioxane as the chemical shift reference (dioxane $67.4 \mathrm{ppm}$ ). In addition to a broadband decoupled carbon spectrum, several spectra were recorded using single-frequency proton decoupling, and a fully coupled spectrum was also collected. The results of these experiments are summarized in Table 3 .

Both the lack of a titratable group (by UV spectroscopy) and the NOEs between the resonances at 7.61 ppm and $5.54 \mathrm{ppm}\left({ }^{1} \mathrm{H}\right.$ NMR) suggest that the new moiety in $\mathbf{3}$ is attached to the rest of the molecule through the hydroxyl group at position 6 ; the ${ }^{13} \mathrm{C}$ NMR results presented in Table 3 reveal that the group $R_{3}$ contains six carbon atoms, two of which are non-protonated (166.13 ppm and $141.90 \mathrm{ppm}$ ). The $166.13 \mathrm{ppm}$ resonance is suggestive of a conjugated carboxyl group, while the $141.90 \mathrm{ppm}$ resonance should arise from an $s p^{2}$ carbon attached to a heteroatom (oxygen in this case). The connectivities of the four protonated carbons are known (from the proton homonuclear and heteronuclear decoupling); both the ${ }^{1} \mathrm{H}$ and ${ }^{13} \mathrm{C}$ results indicate that the carbons at $101.57,70.09$, and $66.17 \mathrm{ppm}$ are attached to oxygen (two oxygens for $101.57 \mathrm{ppm}$ ). These data suggest that $\mathrm{R}_{3}$ has the elemental composition $\mathrm{C}_{6} \mathrm{O}_{5} \mathrm{H}_{7}$, which is confirmed by the ready loss of a 158 fragment in the FD-MS $\left(\mathrm{C}_{6} \mathrm{O}_{5} \mathrm{H}_{7}=159\right)$. The proposed structure for $R_{3}$ is that of an unsaturated sugar acid, 4-deoxy$\alpha$-L-threo-hex-4-enopyranuronate: ${ }^{\dagger}$

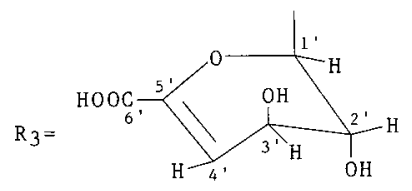

The four protons in positions $1^{\prime} \sim 4^{\prime}$ must all be gauche to their neighbors $\left({ }^{3} J_{\mathrm{H}-\mathrm{H}}<4 \mathrm{~Hz}\right)$, and the large ${ }^{1} J_{\mathrm{C}-\mathrm{H}}$ at position $1^{\prime}(173 \mathrm{~Hz})$ indicates that the anomeric proton is equatorially oriented ${ }^{5)}$. The small coupling of the $\mathbf{H}-2^{\prime}$ and $\mathrm{H}-4^{\prime}$ resonances is consistent with a orientation of the four bonds connecting the protons ${ }^{6}$. The addition of sodium borate to a $\mathrm{D}_{2} \mathrm{O}$ solution of 3 $(\mathrm{pH}$ meter reading $=9.0)$ caused only minor changes in the ${ }^{13} \mathrm{C}$ NMR spectrum of the compound, indicating that the hydroxyl groups at $2^{\prime}$ and $3^{\prime}$ are not oriented cis to each other ${ }^{7)}$. The accumulated NMR results indicate that $\mathrm{R}_{\mathbf{3}}$ adopts a half-chair conformation similar to that reported for the tri-acetyl methyl ester of the parent sugar ${ }^{8)}$ :

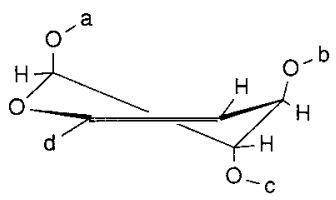

3: $\mathrm{a}=\mathrm{A} 58365 \mathrm{~A}$ dimethyl ester, $\mathrm{b}=\mathrm{c}=\mathrm{H}, \mathrm{d}=\mathrm{COOH}$; Methyl triacetyl-4-deoxy- $\alpha$-L-threo-hex-4-enopyranuronate: $a=b=c=\mathrm{COCH}_{3}, d=\mathrm{COOCH}_{3}$.

$\dagger$ Note that the enantiomeric structure $R_{3}^{\prime}$ is equally probable on the basis of the observed NMR parameters:

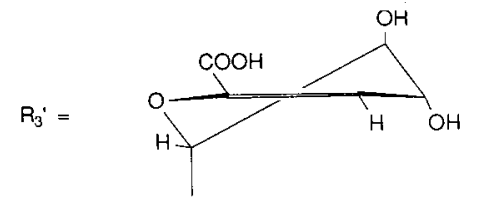


Since the dimethyl ester of A58365A is inactive in the in vitro $\mathrm{ACE}$ inhibition assay ${ }^{1)}, 3$ was hydrolyzed to the free acid with $0.5 \mathrm{~N} \mathrm{NaOH}$ prior to assay. The free acid (5) gave an $\mathrm{IC}_{50}$ of $1 \times 10^{-6} \mathrm{M}$, two orders of magnitude less active than A58365A.

\section{References}

1) O'Connor, S. \& P. Somers: Methods for the detection and quantitation of angiotensin converting enzyme inhibitors in fermentation broths. J. Antibiotics 38: $993 \sim 996,1985$

2) Nakatsukasa, W. M.; R. M. Wilgus, D. N. Thomas, F. P. Mertz \& L. D. Boeck: Angiotensin converting enzyme inhibitors produced by Streptomyces chromofuscus. Discovery, taxonomy, and fermentation. J. Antibiotics 38: $997 \sim 1002,1985$

3) Mynderse, J. S.; S. K. Samlaska, D. S. Fukuda, R. H. DU Bus \& P. J. BAKER: Isolation of A58365A and A58365B, angiotensin converting enzyme inhibitors produced by Streptomyces chromofuscus. J. Antibiotics 38: $1003 \sim 1007,1985$
4) Hunt, A. H.; J. S. Mynderse, S. K. Samlaska, D. S. FuKudA, G. M. MaciaK, H. A. KirST, J. L. OCCOLOWITZ, J. K. Swartzendruber \& N. D. Jones: Structure elucidation of A58365A and A58365B, angiotensin converting enzyme inhibitors produced by Streptomyces chromofuscus. J. Antibiotics 41: $771 \sim 779,1988$

5) Bock, K.; I. Lundt \& C. Pedersen: Assignment of anomeric structure to carbohydrates through geminal ${ }^{13} \mathrm{C}-\mathrm{H}$ coupling constants. Tetrahedron Lett. 1973: $1037 \sim 1040,1973$.

6) Alföldi, J.; R. Palovčík, C. Peciar, J. Hirsch \& P. Kováč: Conformation of some derivatives of methyl 4-deoxy- $\alpha$ - and - $\beta$-L-threo-hex-4-enopyranuronate. Carbohyd. Res. 44: $133 \sim 137,1975$

7) Voelter, W.; C. Bürvenich \& E. Breitmaier: Complex shift reagent for ${ }^{13} \mathrm{C}$ NMR studies on carbohydrates. Angew. Chem. Internat. Edit. 11:539 540, 1972

8) Blattner, R.; R. J. Ferrier \& P. C. Tyler: Unsaturated carbohydrates. Part 22. Alkenes from 5-bromohexopyranose derivatives. J. Chem. Soc. Perkin I 1980: $1535 \sim 1539,1980$ 